\title{
PHOSPHORUS SORPTION ISOTHERMS IN SOILS OF THE SEMIARID REGION OF BRAZIL ${ }^{1}$
}

\author{
MONTESQUIEU DA SILVA VIEIRA ${ }^{2}$, FÁBIO HENRIQUE TAVARES DE OLIVEIRA ${ }^{3}$, MARCELO TAVARES \\ GURGEL $^{3}$, HEMMANNUELLA COSTA SANTOS $^{*}$, HERNANE ARLLEN MEDEIROS TAVARES ${ }^{3}$
}

\begin{abstract}
The soils of the Semiarid region of Brazil lack studies regarding sorption processes and availability of phosphorus (P). Therefore, the objective of this work was to quantify the sorption of $\mathrm{P}$ in ten soils representative of the Semiarid region of Brazil and correlate them with the soil phosphorus storage capacity. The $\mathrm{P}$ concentrations in the equilibrium solutions used to model the sorption isotherms were: $0,5,10$, 15, 20, 30, 40, 55, 70, and $80 \mathrm{mg} \mathrm{L}^{-1}$ for the soils Typic Quartzipsamment (Neossolo Quartzarenico), Typic Hapludox (Latossolo Vermelho Amarelo), Typic Hapludult (Argissolo Vermelho Amarelo), Typic Quartzipsamment (Neossolo Flúvico), and Typic Dystrudept (Cambissolo Haplico); and 0, 10, 15, 25, 40, 55, 80, 100, 130, and $150 \mathrm{mg} \mathrm{L}^{-1}$ for the soils Typic Calciudolls (Chernossolo Rendzico), Typic Dystrudept (Cambissolo Haplico), Typic Dystrudept (Cambissolo Haplico), Typic Hapludult (Argissolo Vermelho Amarelo), and Typic Hapludert (Vertissolo Haplico). The Langmuir and Freundlich sorption isotherms were fitted to non-linear regression models and the values of the model parameters were estimated. The sorption isotherms were adequate to quantify the sorption of $\mathrm{P}$ in the soils of the Semiarid region of Brazil, with maximum $\mathrm{P}$ sorption capacity varying from $50.4 \mathrm{mg} \mathrm{kg}^{-1}$ to $883.5 \mathrm{mg} \mathrm{kg}^{-1}$. The sorption of $\mathrm{P}$ was higher in soils with more clayey textures, alkaline, and rich in iron and calcium, denoting the importance of evaluating the effect of these characteristics on the sorption of $\mathrm{P}$ in these soils.
\end{abstract}

Keywords: Precipitation. Adsorption. Soil phosphorus storage capacity.

\section{ISOTERMAS DE SORÇÃO DE FÓSFORO EM SOLOS DO SEMIÁRIDO}

RESUMO - Os solos do semiárido brasileiro ainda não foram suficientemente estudados quanto aos processos de sorção e de disponibilidade de fósforo (P). Nesse sentido objetivou-se com este trabalho quantificar a sorção de $\mathrm{P}$ em dez solos representativos da região semiárida e correlacioná-las com o Fator Capacidade de Fósforo do Solo (FCP). As concentrações de $\mathrm{P}$ das soluções de equilíbrio utilizadas para o ajuste dessas isotermas corresponderam a $0 ; 5 ; 10 ; 15 ; 20 ; 30 ; 40 ; 55 ; 70$ e $80 \mathrm{mg} \mathrm{L}^{-1}$ de $\mathrm{P}$ para os solos Neossolo Quartzarênico (Entisol), Latossolo Vermelho Amarelo (Oxisol), Argissolo Vermelho Amarelo (Ultisol), Neossolo Flúvico (Entisol) e Cambissolo Háplico (Inceptsol); e a $0 ; 10 ; 15 ; 25 ; 40 ; 55 ; 80 ; 100 ; 130$ e $150 \mathrm{mg} \mathrm{L}^{-1}$ para os solos Chernossolo Rêndzico (Mollisol), Cambissolo Háplico (Inceptsol), Cambissolo Háplico (Inceptsol), Argissolo Vermelho Amarelo (Ultisol) e Vertissolo Háplico (Vertisol). As isotermas de Langmuir e de Freundlich foram ajustadas por meio da técnica de regressão não-linear e estimados os valores dos parâmetros desses modelos. As isotermas mostraram-se adequadas para quantificar a sorção de $\mathrm{P}$ nos solos do semiárido, com valores de capacidade máxima de sorção de $\mathrm{P}$ (CMSP) variando de $50,4 \mathrm{mg} \mathrm{kg}^{-1}$ a $883,5 \mathrm{mg} \mathrm{kg}^{-1}$. O P foi sorvido em maior quantidade nos solos mais argilosos, alcalinos e ricos em ferro e cálcio, evidenciando a importância da avaliação dessas características na sorção de P nesses solos.

Palavras-chave: Precipitação. Adsorção. Fator capacidade de P.

\footnotetext{
${ }^{*}$ Corresponding author

${ }^{1}$ Received for publication in $08 / 04 / 2019$; accepted in $10 / 14 / 2020$.

Paper extracted from the doctoral thesis of the first author.

${ }^{2}$ Coordination of Higher Education in Agroecology, Instituto Federal de Educação, Ciência e Tecnologia da Paraíba, Picuí, PB, Brazil; montesquieu.vieira@ifpb.edu.br - ORCID: 0000-0003-3763-6662.

${ }^{3}$ Department of Agricultural and Forest Sciences, Universidade Federal Rural do Semi-Árido, Mossoró, RN, Brazil; fabio@ufersa.edu.br ORCID: 0000-0001-8581-8482, marcelo.tavares@ufersa.edu.br - ORCID: 0000-0001-7457-0645, hernanearllen@hotmail.com - ORCID: 0000-0002-5044-2654.

${ }^{4}$ Department of Educational Development, Instituto Federal de Educação, Ciência e Tecnologia de Pernambuco, Vitória de Santo Antão, PE, Brazil; hecosantos@vitoria.ifpe.edu.br-ORCID: 0000-0003-4871-1875.
} 


\section{INTRODUCTION}

The sorption of phosphorus $(\mathrm{P})$ in soils is the main cause of low efficiency of applications of $\mathrm{P}$ fertilizers, since most $\mathrm{P}$ fertilizers applied are usually sorbed to the soil and a small part are available to plants (NOVAIS; SMITH, 1999).

Several regression models for description and quantifying of $\mathrm{P}$ sorption in soils have been used in studies about $\mathrm{P}$ sorption processes, and the Langmuir and Freundlich sorption isotherms stand out among these models (COSTA et al., 2014; HADGU et al., 2014; TAMUNGANG et al., 2016; BRITO NETO et al., 2018).

The use of Langmuir and Freundlich sorption isotherms enables the evaluation of effects of several soil characteristics on the sorption of $\mathrm{P}$ in soils (SIMS; PIERZYNSKI, 2005). These effects have been found mainly for maximum $P$ sorption capacity (MPSC), clay contents, remaining P (P-rem), iron and aluminum oxide contents, $\mathrm{pH}$, organic matter contents, and exchangeable aluminum contents (HADGU et al., 2014; ALBUQUERQUE et al., 2016; SANTOS et al., 2016; TAMUNGANG et al., 2016; ARRUDA et al., 2017; BRITO NETO et al., 2018; SANTOS et al., 2018; TEIXEIRA; SOUSA; VALE, 2018). The Soil Phosphorus Storage Capacity (SPSC) denotes the soil capacity to retain P in the solution; P-rem and MPSC are the most determinant characteristics of the SPSC (BROGGI et al., 2011).

Despite the importance of studies about sorption of $\mathrm{P}$, most studies in Brazil have not considered soils of the Semiarid region. Moreover, little information is found about this process in these soils, such as the studies of Godinho et al. (1997), Moreira et al. (2006), and Bezerra et al. (2013), who evaluated soils in the sates of Rio Grande do Norte $(\mathrm{RN})$ and Ceará (CE). The soil MPSC is important to know the soil $\mathrm{P}$ drain size and develop interpretation tables for soil analysis and recommend soil $\mathrm{P}$ fertilizers, because the higher the MPSC, the higher the recommended $\mathrm{P}$ rate.

In this context, the objective of this work was to quantify the sorption of $\mathrm{P}$ in ten soils representative of the Semiarid region of Brazil at the Piranhas-Açu (RN) and Jaguaribe (CE) River Valleys and correlate them with the SPSC.

\section{MATERIAL AND METHODS}

The sorption of phosphorus (P) was evaluated in samples of the $0-0.30 \mathrm{~m}$ layer of ten noncultivated soils representative of the Semiarid region of Brazil at the Piranhas-Açu (RN) and Jaguaribe (CE) River Valleys.

These soils were formed from different material of origin. Six soils were from limestone: three Typic Dystrudept (Cambissolo Haplico) in Baraúna, RN (CHB; 0505'42.2"S; 37³6'46.7"W), Quixeré, CE (CHQ; 0505'07.7"S; 037 51'35.1"W), and Afonso Bezerra, RN (CHQ; 05 $27^{\prime} 26.40 " \mathrm{~S} ; 036^{\circ}$ 41'42.40"W); one Typic Calciudolls (Chernossolo Rendzico) in Mossoró, RN (CRM; 05²6'54.7"S; 037¹1'19.9"W); one Typic Hapludult (Argissolo Vermelho Amarelo) in Apodi, RN (AVA; 05 37'22.2"S; 037 48'52.7"W); and one Typic Hapludert (Vertissolo Haplico) in Mossoró, RN (VHM; $05^{\circ}$ $25^{\prime} 26.4^{\prime \prime} \mathrm{S}$; $037^{\circ} 12^{\prime} 26^{\prime \prime} \mathrm{W}$ ); one soil was from alluvial sediments: Typic Quartzipsamment (Neossolo Flúvico) in Carnaubais, RN (NFC; 05²2'33.2"S; $\left.036^{\circ} 50^{\prime} 42.2^{\prime \prime} \mathrm{W}\right)$; one soil was from arenite: Typic Quartzipsamment (Neossolo Quartzarênico) in Russas, CE (NQR; 0501'58.3"S; 03807'12.7"W); and two soils were from sediments of the Barreiras Group: one Typic Hapludult (Argissolo Vermelho Amarelo) in Mossoró, RN (AVM; 0509'58.5"S; $037^{\circ} 11^{\prime} 57.6^{\prime \prime W}$ ); and one Typic Hapludox (Latossolo Vermelho Amarelo) in Mossoró, RN (LVM; 04 56'13.8"; 037²7'30.0"W) (BRASIL, 1971).

The soil samples were air dried, crushed, sieved to obtain the bulk soil, and characterized for chemical and physical attributes, according to Teixeira et al. (2017) (Table 1). The remaining $\mathrm{P}$ (P-rem) was analyzed according to Alvarez V. et al. (2000), by shaking the soil samples with a $\mathrm{CaCl}_{2} 0.01 \mathrm{~mol} \mathrm{~L}^{-1}$ solution and $60 \mathrm{mg} \mathrm{L}^{-1}$ of $\mathrm{P}$ for five minutes, and leaving it to rest for decantation for 16 hours. The $\mathrm{P}$ contents in the extract was then quantified by molecular absorption spectrophotometry (BRAGA; DEFELIPO, 1974).

The Langmuir and Freundlich sorption isotherms were modeled according to Farias et al. (2009) and Alvarez V. et al. (2000). The P concentrations in the equilibrium solutions used to model the sorption isotherms were: $0,5,10,15,20$, $30,40,55,70$, and $80 \mathrm{mg} \mathrm{L}^{-1}$ for the soils Typic Quartzipsamment (Neossolo Quartzarenico), Typic Hapludox (Latossolo Vermelho Amarelo), Typic Hapludult (Argissolo Vermelho Amarelo), Typic Quartzipsamment (Neossolo Flúvico), and Typic Dystrudept (Cambissolo Haplico); and 0, 10, 15, 25, $40,55,80,100,130$, and $150 \mathrm{mg} \mathrm{L}^{-1}$ for the soils Typic Calciudolls (Chernossolo Rendzico), Typic Dystrudept (Cambissolo Haplico), Typic Dystrudept (Cambissolo Haplico), Typic Hapludult (Argissolo Vermelho Amarelo), and Typic Hapludert (Vertissolo Haplico).

An aliquot of $2.5 \mathrm{~cm}^{3}$ of each soil sample was weighed and added to $125-\mathrm{mL}$ Erlenmeyer flasks; $25 \mathrm{~mL}$ of a $\mathrm{CaCl}_{2} 0.01 \mathrm{~mol} \mathrm{~L}^{-1}$ solution containing $\mathrm{P}$, according to each concentration, was then added. The flasks were horizontally shaken for 24 hours and the suspensions were filtered in qualitative filter paper. The $\mathrm{P}$ contents in the equilibrium solution (supernatant) was quantified by colorimetry 
(BRAGA; DEFELIPO, 1974). The quantity of P sorbed to the soil was estimated by the difference between the initial $\mathrm{P}$ concentration in the equilibrium solution and the remaining $\mathrm{P}$ concentration after the shaking and filtration. This procedure was performed with three replications.

Table 1. Physical and chemical characteristics of ten soils of the Semiarid region of Brazil.

\begin{tabular}{|c|c|c|c|c|c|c|c|c|c|c|}
\hline \multirow{2}{*}{ Characteristics } & \multicolumn{10}{|c|}{ Soils } \\
\hline & NQR & $\overline{L V M}$ & AVM & NFC & $\overline{\mathrm{CHA}}$ & CRM & $\mathrm{CHB}$ & $\mathrm{CHQ}$ & AVA & VHM \\
\hline Sand $\left(\mathrm{g} \mathrm{kg}^{-1}\right)$ & 920 & 940 & 850 & 640 & 680 & 290 & 660 & 380 & 520 & 290 \\
\hline Silt $\left(\mathrm{g} \mathrm{kg}^{-1}\right)$ & 40 & 10 & 20 & 22 & 70 & 160 & 70 & 220 & 90 & 320 \\
\hline Clay $\left(\mathrm{g} \mathrm{kg}^{-1}\right)$ & 40 & 50 & 130 & 140 & 250 & 550 & 270 & 400 & 390 & 390 \\
\hline Soil density $\left(\mathrm{g} \mathrm{cm}^{-3}\right)$ & 1.64 & 1.58 & 1.56 & 1.35 & 1.39 & 1.20 & 1.42 & 1.36 & 1.37 & 1.27 \\
\hline P-rem $\left(\mathrm{mg} \mathrm{L}^{-1}\right)$ & 57.9 & 58.8 & 52.1 & 49.1 & 22.7 & 12.1 & 33.0 & 11.6 & 25.9 & 18.1 \\
\hline $\mathrm{pH}$ & 5.6 & 4.6 & 4.1 & 6.5 & 6.7 & 7.6 & 6.6 & 6.7 & 7.5 & 8.0 \\
\hline $\operatorname{SOM}\left(\mathrm{g} \mathrm{kg}^{-1}\right)$ & 5.1 & 2.4 & 7.5 & 6.2 & 9.1 & 14.4 & 9.4 & 11.0 & 5.5 & 7.0 \\
\hline P Mehlich-1 (mg dm $\left.{ }^{-3}\right)$ & 5.0 & 3.3 & 4.2 & 60.7 & 2.0 & 3.1 & 4.5 & 4.8 & 3.7 & 1.6 \\
\hline $\mathrm{Fe}_{2} \mathrm{O}_{3}\left(\mathrm{~g} \mathrm{~kg}^{-1}\right)$ & 1.86 & 2.14 & 12.69 & 45.23 & 23.01 & 72.86 & 47.07 & 121.39 & 44.12 & 50.03 \\
\hline $\mathrm{K}^{+}\left(\mathrm{mg} \mathrm{dm}^{-3}\right)$ & 53.3 & 16.7 & 35.7 & 137.3 & 184.3 & 185.8 & 144.8 & 149.5 & 233.9 & 64.0 \\
\hline $\mathrm{Na}^{+}\left(\mathrm{mg} \mathrm{dm}^{-3}\right)$ & 8.5 & 7.6 & 20.1 & 133.1 & 20.9 & $\begin{array}{l}47.1 \\
47.1\end{array}$ & 54.0 & 116.3 & 40.0 & 76.2 \\
\hline $\mathrm{Ca}^{2+}\left(\mathrm{cmol}_{\mathrm{C}} \mathrm{dm}^{-3}\right)$ & 0.89 & 0.24 & 0.74 & 6.94 & 12.23 & 40.33 & 6.04 & 11.50 & 9.33 & 35.73 \\
\hline $\mathrm{Mg}^{2+}\left(\mathrm{cmol}_{\mathrm{C}} \mathrm{dm}^{-3}\right)$ & 0.73 & 0.25 & 0.29 & 3.10 & 1.68 & 4.77 & $1 ., 17$ & 1.29 & 3.03 & 5.60 \\
\hline $\mathrm{Al}^{3+}\left(\mathrm{cmol}_{\mathrm{C}} \mathrm{dm}^{-3}\right)$ & 0.10 & 0.24 & 0.61 & 0.00 & 0.00 & 0.00 & 0.00 & 0.00 & 0.00 & 0.00 \\
\hline$(\mathrm{H}+\mathrm{Al})\left(\mathrm{cmol}_{\mathrm{C}} \mathrm{dm}^{-3}\right)$ & 1.71 & 1.23 & 4.02 & 1.19 & 1.81 & 0.15 & 1.58 & 1.97 & 0,13 & 0.00 \\
\hline SB $\left(\mathrm{cmol}_{\mathrm{C}} \mathrm{dm}^{-3}\right)$ & 1.79 & 0.56 & $\begin{array}{l}4.02 \\
1.20\end{array}$ & 10.97 & $\begin{array}{l}1.01 \\
14.47\end{array}$ & 45.78 & $\begin{array}{l}1.00 \\
7.81\end{array}$ & 13.68 & 13.13 & 41.83 \\
\hline $\mathrm{CECe}\left(\mathrm{cmol}_{\mathrm{C}} \mathrm{dm}^{-3}\right)$ & 1.89 & 0.80 & $\begin{array}{l}1.20 \\
1.81\end{array}$ & 10.97 & 14.47 & 45.78 & $\begin{array}{l}7.01 \\
7.81\end{array}$ & $\begin{array}{l}15.00 \\
13.68\end{array}$ & 13.13 & 41.83 \\
\hline $\operatorname{CEC}\left(\mathrm{cmol}_{\mathrm{C}} \mathrm{dm}^{-3}\right)$ & 3.50 & 1.79 & 5.22 & 12.16 & 16.28 & 45.93 & 9.39 & 15.65 & 13.26 & 41.83 \\
\hline BS $(\%)$ & 51 & 31 & 23 & 90 & 89 & 100 & 83 & 87 & 99 & 100 \\
\hline AS (\%) & 5 & 30 & 34 & 0 & 0 & 0 & 0 & 0 & 0 & 0 \\
\hline $\operatorname{ESP}(\%)$ & 1 & 2 & 2 & 5 & 1 & 0 & 3 & 3 & 1 & 1 \\
\hline
\end{tabular}

NQR = Typic Quartzipsamment (Neossolo Quartzarênico) in Russas (CE); LVM = Typic Hapludox (Latossolo Vermelho Amarelo) in Mossoró (RN); AVM = Typic Hapludult (Argissolo Vermelho Amarelo) in Mossoró (RN); NFC = Typic Quartzipsamment (Neossolo Flúvico) in Carnaubais (RN); CHA = Typic Dystrudept (Cambissolo Haplico) in Afonso Bezerra (RN); CRM = Typic Calciudolls (Chernossolo Rendzico) in Mossoró (RN); CHB = Typic Dystrudept (Cambissolo Haplico) in Baraúna (RN); CHQ = Typic Dystrudept (Cambissolo Haplico) in Quixeré (CE); AVA = Typic Hapludult (Argissolo Vermelho Amarelo) in Apodi (RN); VHM = Typic Hapludert (Vertissolo Haplico) in Mossoró (RN); $\mathrm{SOM}=$ soil organic matter contents; $\mathrm{Fe}_{2} \mathrm{O}_{3}=$ iron extracted by sulfuric attack on bulk soil, data from Paiva (2019); $\mathrm{SB}=\mathrm{Sum}$ of bases; $\mathrm{CECe}=$ effective cation exchange capacity; $\mathrm{CEC}=$ cation exchange capacity potential; $\mathrm{BS}(\%)=$ base saturation; AS $(\%)=$ aluminum saturation; $\mathrm{ESP}=$ exchangeable sodium percentage.

The Langmuir sorption isotherm of each soil was fitted to non-linear regression models (single region), which showed to be the best linearization technique (FARIAS et al., 2009), according to Equation 1:

$$
Q=(a b C) /(1+a C)
$$

where:

$Q=$ quantity of $\mathrm{P}$ sorbed in the soil,

$C=$ concentration of $\mathrm{P}$ in the equilibrium solution,

$a=$ constant of the model that estimates the binding energy of $\mathrm{P}$ to the soil, and

$b=$ constant of the model, whose estimate is the soil maximum $P$ sorption capacity (MPSC).

This technique was also used for the model of the Freundlich sorption isotherm, using Equation 2:

$$
Q=k C^{-n}
$$

where:
$Q=$ quantity of $\mathrm{P}$ sorbed in the soil,

$C=$ concentration of $\mathrm{P}$ in the equilibrium solution,

$k$ and $n=$ constants of the model related to soil capacity to sorb $\mathrm{P}$ from the equilibrium solution.

The parameters of the models fitting the two $P$ sorption isotherms were estimated and

correlation analyses were carried out for the values of these parameters and for clay contents, MPSC, and P-rem.

\section{RESULTS AND DISCUSSION}

The high coefficients of correlation between the data estimated by hyperbolical model of Langmuir and the observed data varied from 0.9634 to 0.9867 (Figures 1 and 2). This result indicates that this model adequately describes the sorption of phosphorus $(\mathrm{P})$ in the soils studied, as found by Chaves et al. (2009), Farias et al. (2009), Corrêa, Nascimento and Rocha (2011), and Hadgu et al. (2014). 

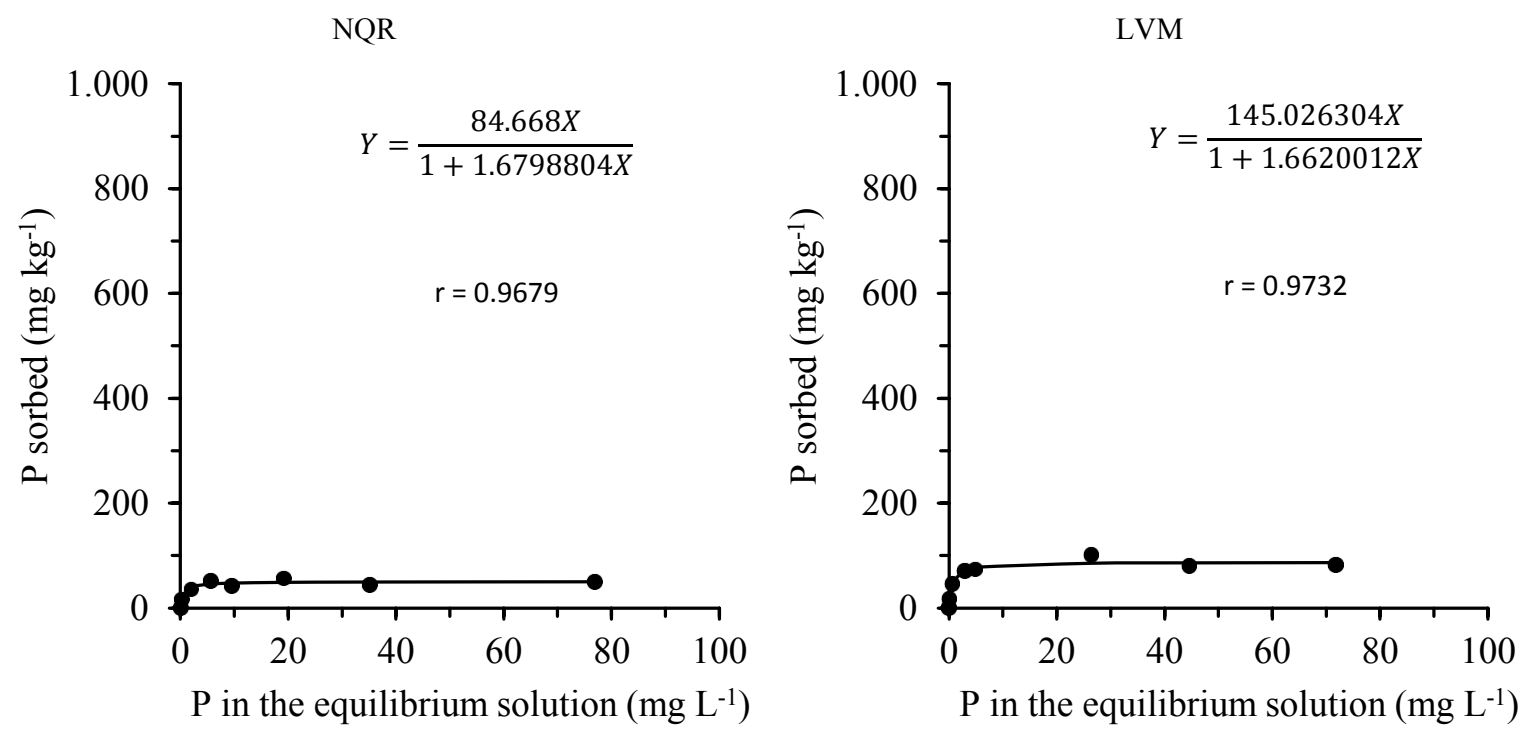

AVM
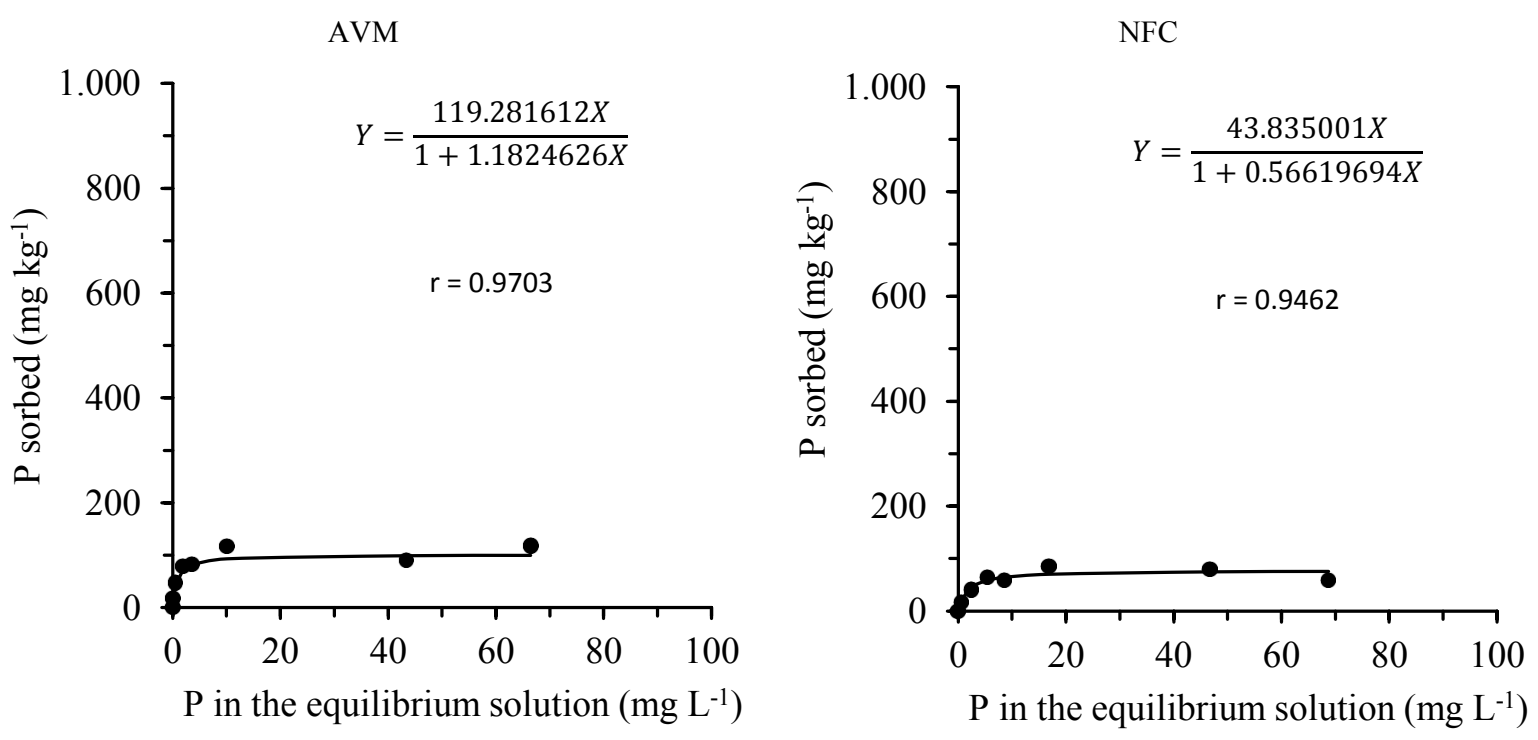

CHB
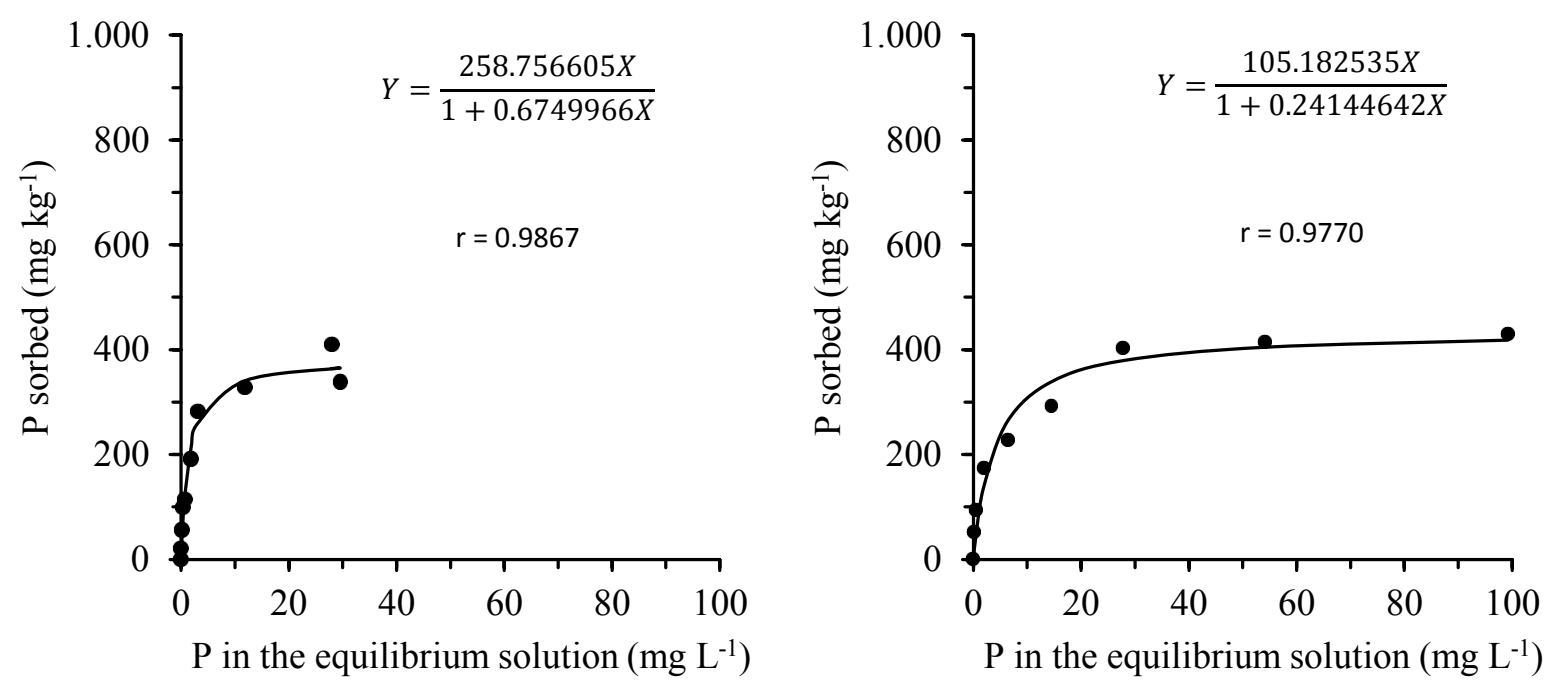

NQR = Typic Quartzipsamment (Neossolo Quartzarênico); LVM = Typic Hapludox (Latossolo Vermelho Amarelo); AVM = Typic Hapludult (Argissolo Vermelho Amarelo); NFC = Typic Quartzipsamment (Neossolo Flúvico); CHA = Typic Dystrudept (Cambissolo Haplico); CHB = Typic Dystrudept (Cambissolo Haplico)

Figure 1. Langmuir sorption isotherm for data of quantity of $P$ sorbed in different soils. 


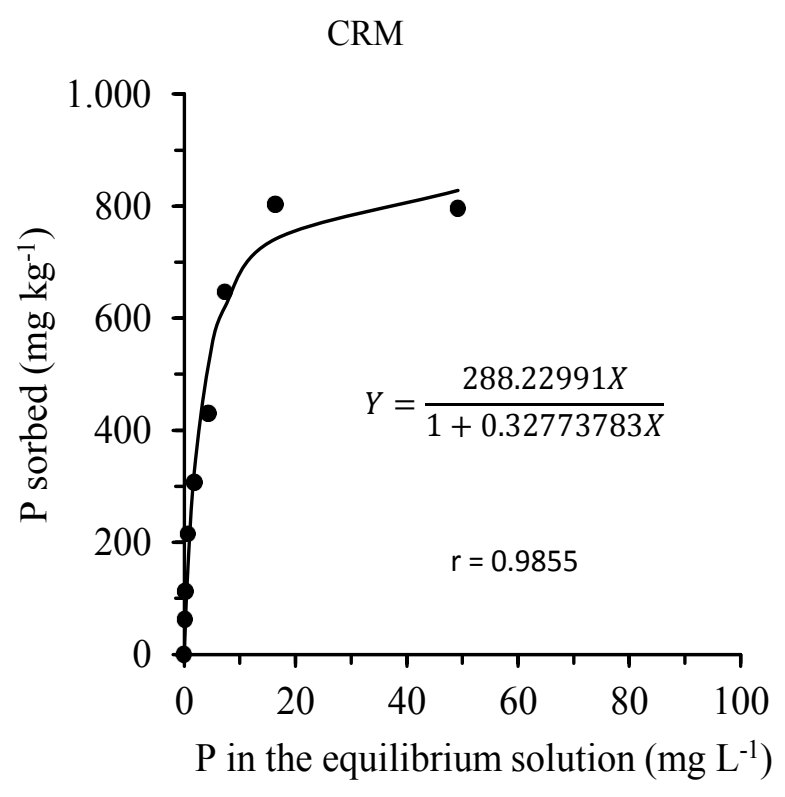

AVA

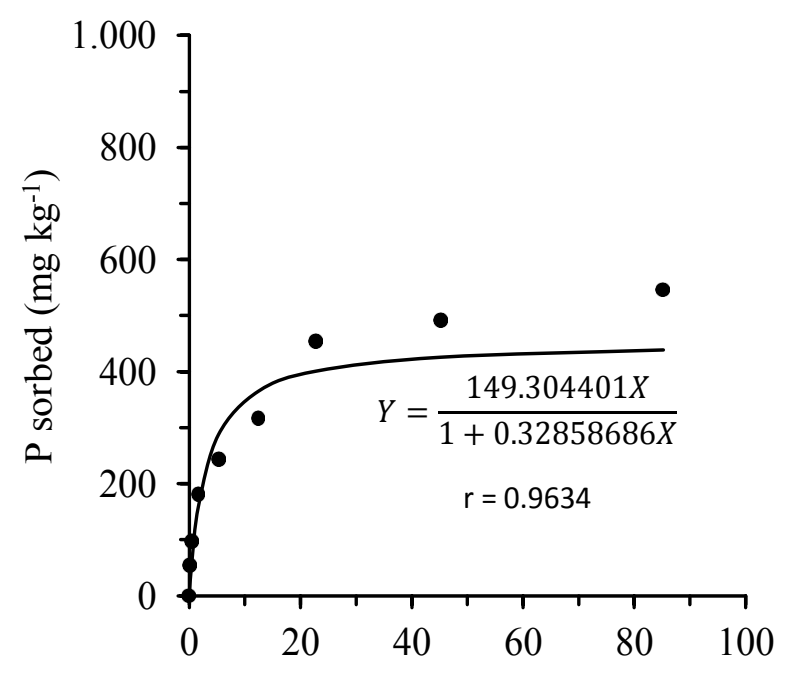

$\mathrm{P}$ in the equilibrium solution $\left(\mathrm{mg} \mathrm{L}^{-1}\right)$

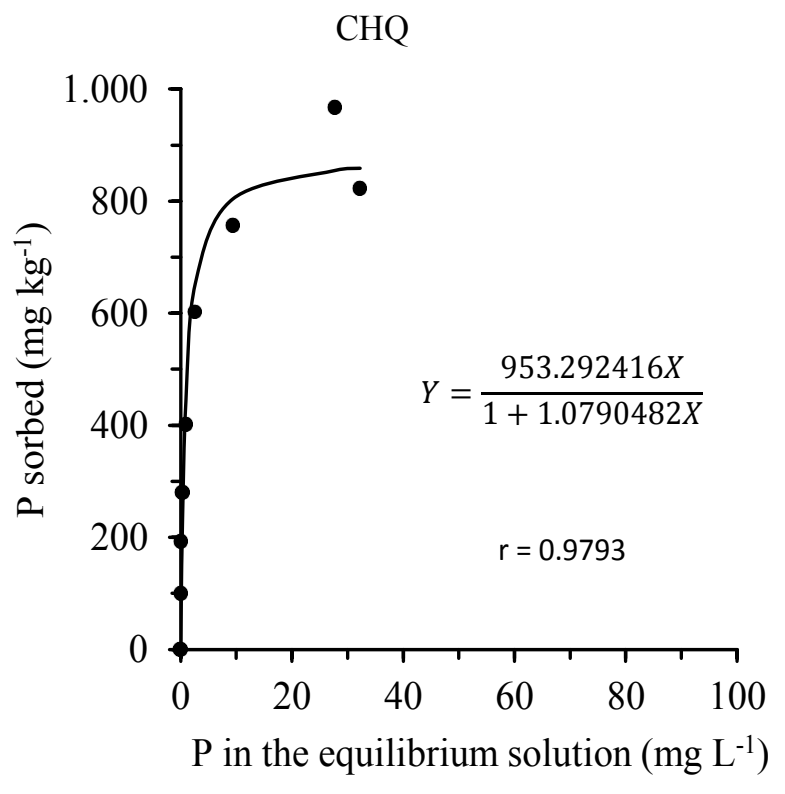

VHM

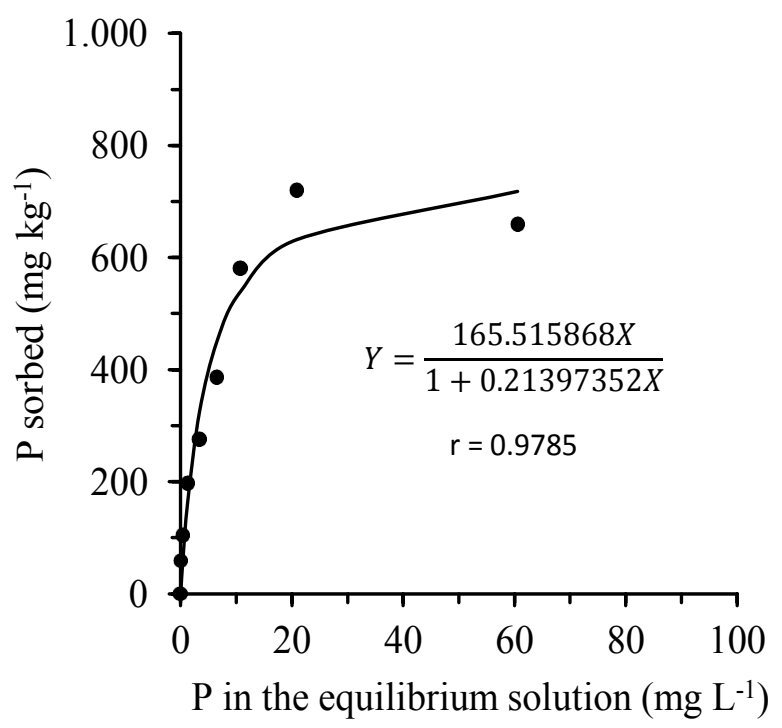

$\mathrm{CRM}=$ Typic Calciudolls (Chernossolo Rendzico); CHQ = Typic Dystrudept (Cambissolo Haplico); AVA = Typic Hapludult (Argissolo Vermelho Amarelo); VHM = Typic Hapludert (Vertissolo Haplico)

Figure 2. Langmuir sorption isotherm for data of quantity of $\mathrm{P}$ sorbed in different soils.

The sorption of $\mathrm{P}$ increased as the concentration of $\mathrm{P}$ in the equilibrium solution was increased in all soils studied. However, after reach the equilibrium of chemical reactions, this increase stopped, enabling the estimation of the maximum $\mathrm{P}$ sorption capacity (MPSC) by fitting the data to the Langmuir sorption isotherm (Figures 1 and 2, and Table 2).

This dynamic was also found by Godinho et al. (1997), Chaves et al. (2009), Pinto et al. (2013), and Rossi, Rollán and Bachmeier (2016), since the sorption of $\mathrm{P}$ decreases as the $\mathrm{P}$ adsorption sites in the soil colloids are saturated and the $\mathrm{Al}^{3+}, \mathrm{Fe}^{3+}$, and
$\mathrm{Ca}^{2+}$ activities in the soil solution decrease due to the precipitation of these cations combined with $\mathrm{P}$. Therefore, the $\mathrm{P}$ sorption stops because of increases in $\mathrm{P}$ concentration in the equilibrium solution (HADGU et al., 2014).

The MPSC varied from $50.40 \mathrm{mg} \mathrm{kg}^{-1}$ in the NQR to $883.45 \mathrm{mg} \mathrm{kg}^{-1}$ in the CHQ, which enables the distinguishing of three group of soils: NQR, LVM, AVM, and NFC, with low MPSC (mean of $78.9 \mathrm{mg} \mathrm{kg}^{-1}$ ); CHA, CHB, and AVA, with intermediate MPSC (mean of $424.5 \mathrm{mg} \mathrm{kg}^{-1}$ ); and $\mathrm{CRM}, \mathrm{CHQ}$, and VHM, with high MPSC (mean of $845.5 \mathrm{mg} \mathrm{kg}^{-1}$ ). 
The MPSC results found (Table 2) were similar to those found by Corrêa, Nascimento and Rocha (2011) for ten soils of the state of Pernambuco, Brazil (37.04 to $904.13 \mathrm{mg} \mathrm{kg}^{-1}$ ), but they were higher than those found by Farias et al. (2009) for twelve soils of the state of Paraíba, Brazil (36.0 $\mathrm{mg} \mathrm{kg}^{-1}$ to $435.3 \mathrm{mg} \mathrm{kg}^{-1}$ ).

Table 2. Estimates of parameters of Langmuir and Freundlich sorption isotherms for ten soils of the Semiarid region of Brazil.

\begin{tabular}{ccccc}
\hline \multirow{2}{*}{ Soil } & \multicolumn{2}{c}{ Langmuir sorption isotherm } & \multicolumn{2}{c}{ Freundlich sorption isotherm } \\
\cline { 2 - 5 } & MPSC & $a$ & $k$ & $n$ \\
NQR & $\mathrm{mg} \mathrm{kg}^{-1}$ & $\mathrm{~L} \mathrm{mg}^{-1}$ & 32.2002 & 8.0169 \\
LVM & 50.4016 & 1.6799 & 51.7796 & 7.0150 \\
AVM & 87.2600 & 1.6620 & 61.3122 & 6.2908 \\
NFC & 100.8756 & 1.1825 & 39.5007 & 6.0314 \\
Mean & 77.4201 & 0.5662 & 46.1982 & 6.8385 \\
CHA & 78.9893 & 1.2727 & 153.6844 & 3.5894 \\
CHB & 383.3451 & 0.6750 & 144.1645 & 3.8662 \\
AVA & 435.6351 & 0.2415 & 153.4291 & 3.3355 \\
Mean & 454.3834 & 0.3286 & 150.4260 & 3.5970 \\
CRM & 424.4545 & 0.4150 & 292.9840 & 3.4277 \\
CHQ & 879.4527 & 0.3277 & 405.9710 & 4.1263 \\
VHM & 883.4568 & 1.0791 & 225.9578 & 3.3113 \\
Mean & 773.5344 & 0.2140 & 308.3043 & 3.6218 \\
\hline
\end{tabular}

$\mathrm{NQR}=$ Typic Quartzipsamment (Neossolo Quartzarênico) in Russas (CE); LVM = Typic Hapludox (Latossolo Vermelho Amarelo) in Mossoró (RN); AVM = Typic Hapludult (Argissolo Vermelho Amarelo) in Mossoró (RN); NFC = Typic Quartzipsamment (Neossolo Flúvico) in Carnaubais (RN); CHA = Typic Dystrudept (Cambissolo Haplico) in Afonso Bezerra (RN); CRM = Typic Calciudolls (Chernossolo Rendzico) in Mossoró (RN); CHB = Typic Dystrudept (Cambissolo Haplico) in Baraúna (RN); CHQ = Typic Dystrudept (Cambissolo Haplico) in Quixeré (CE); AVA = Typic Hapludult (Argissolo Vermelho Amarelo) in Apodi (RN); VHM = Typic Hapludert (Vertissolo Haplico) in Mossoró (RN); MPSC = maximum $\mathrm{P}$ sorption capacity; $a=$ binding energy of $\mathrm{P}$ to the soil; $k$ and $n=$ constants of the model related to soil capacity to sorb the $\mathrm{P}$ from the equilibrium solution.

The variations found in the present work denote the large diversity of soil physical, chemical, and mineralogical characteristics of the Semiarid region of Brazil, mainly due to clay, $\mathrm{Ca}^{2+}, \mathrm{Al}^{3+}$, and $\mathrm{Fe}^{3+}$ contents in the soil solution, $\mathrm{pH}$, and mineralogy of the clay fraction (contents of kaolinite and iron and aluminum oxides), which affect the $\mathrm{P}$ adsorption and precipitation in soils.

The high coefficients of correlation between the data estimated by the Freundlich model and the observed data varied from 0.8673 to 0.9899 (Figures 3 and 4), denoting that this model was also able to adequately describe $\mathrm{P}$ sorption in the soils studied. The values found for the constant $k$ of the Freundlich model (Table 2) also enabled the formation of three groups of soils: NQR, LVM, AVM, and NFC, with low P sorption capacity; CHA, CHB, and AVA, with intermediate; and CRM, CHQ, and VHM, with high $\mathrm{P}$ sorption capacity.

The main soil characteristics related to soil phosphorus storage capacity (SPSC) estimated by the sorption isotherms (MPSC and $k$ ) presented high correlations to P-rem ( $\mathrm{r}=-0.949^{* *}$ for MPSC; $\mathrm{r}=-0.902 * *$ for $k)$ and clay $\left(\mathrm{r}=0.915^{* *}\right.$ for MPSC; $\mathrm{r}=0.820^{* *}$ for $k$ ) (Table 3 ). In addition, the correlation between MPSC and $k$ was also high ( $\mathrm{r}=$ $\left.0.954^{* *}\right)$. This indicates that the clay contents and $\mathrm{P}$ rem are good estimators of SPSC, and both can be used for interpretation of $\mathrm{P}$ contents (Mehlich-1) and recommendation of soil $\mathrm{P}$ fertilizers for crops grown in these soils.

However, although the coefficient of correlation between clay and P-rem was good $\left(\mathrm{r}=-0.841^{* *}\right)$ (Table 3$)$, the comparison between some soils showed that P-rem is a better estimator of SPSC than clay contents. This was found for the comparison between the CHQ and AVA; although these soils had practically the same clay contents (Table 1), the MPSC of the CHQ $\left(883.5 \mathrm{mg} \mathrm{kg}^{-1}\right)$ was practically 2-fold that of the AVA (455.5 mg kg${ }^{-1}$ ) (Table 2). The difference in MPSC between CHQ and AVA is not explained by the difference between clay contents, but is clearly shown by the $\mathrm{P}$-rem and $\mathrm{Fe}_{2} \mathrm{O}_{3}$ contents of these soils; the P-rem and $\mathrm{Fe}_{2} \mathrm{O}_{3}$ contents were $11.6 \mathrm{mg} \mathrm{L}^{-1}$ and $121.39 \mathrm{~g} \mathrm{~kg}^{-1}$ for $\mathrm{CHQ}$, and $25.9 \mathrm{mg} \mathrm{L}^{-1}$ and $44.12 \mathrm{~g} \mathrm{~kg}^{-1}$ for AVA, respectively (Table 1), denoting the importance of iron oxides for the $\mathrm{P}$ adsorption in these soils. 

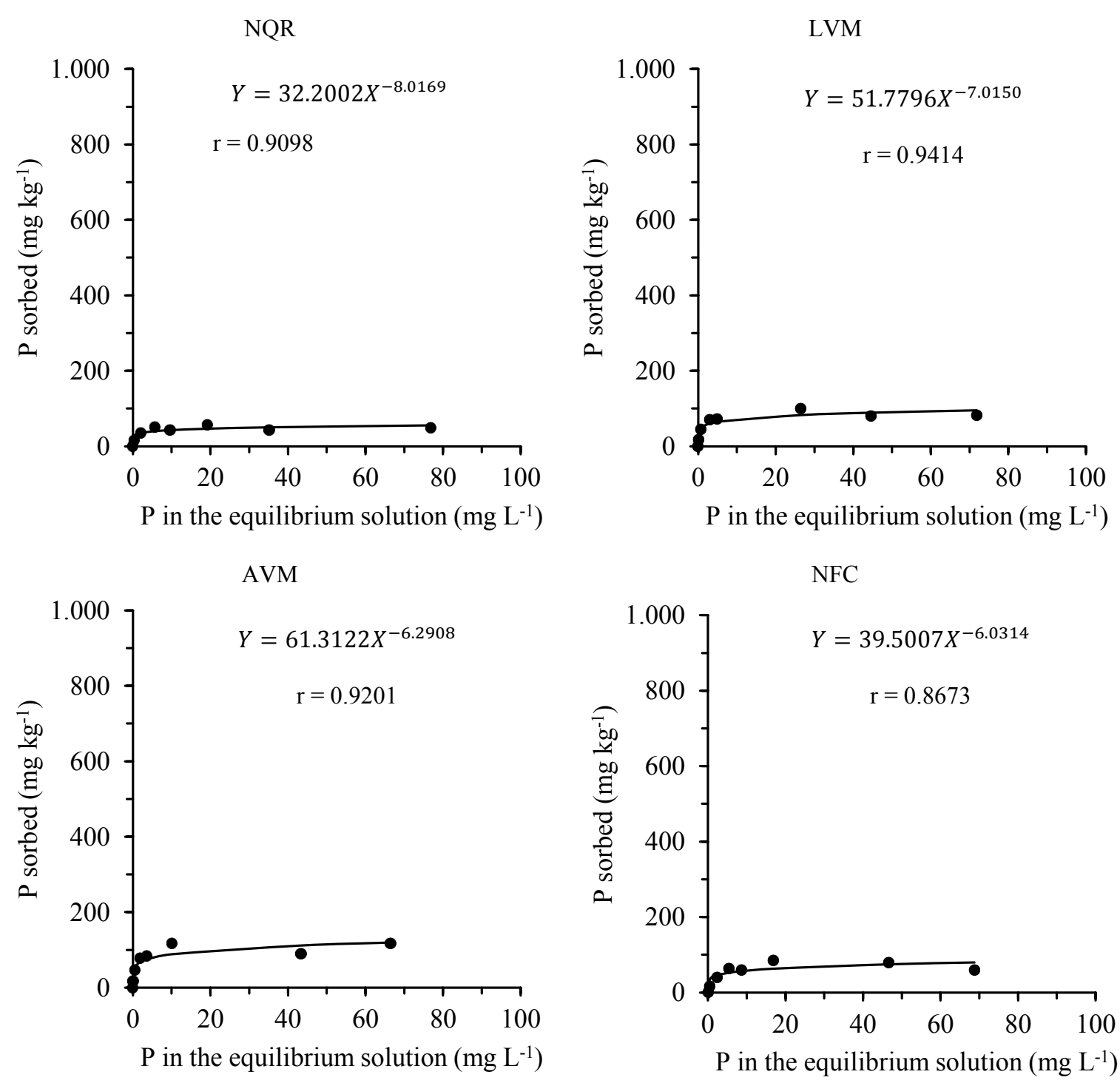

CHA
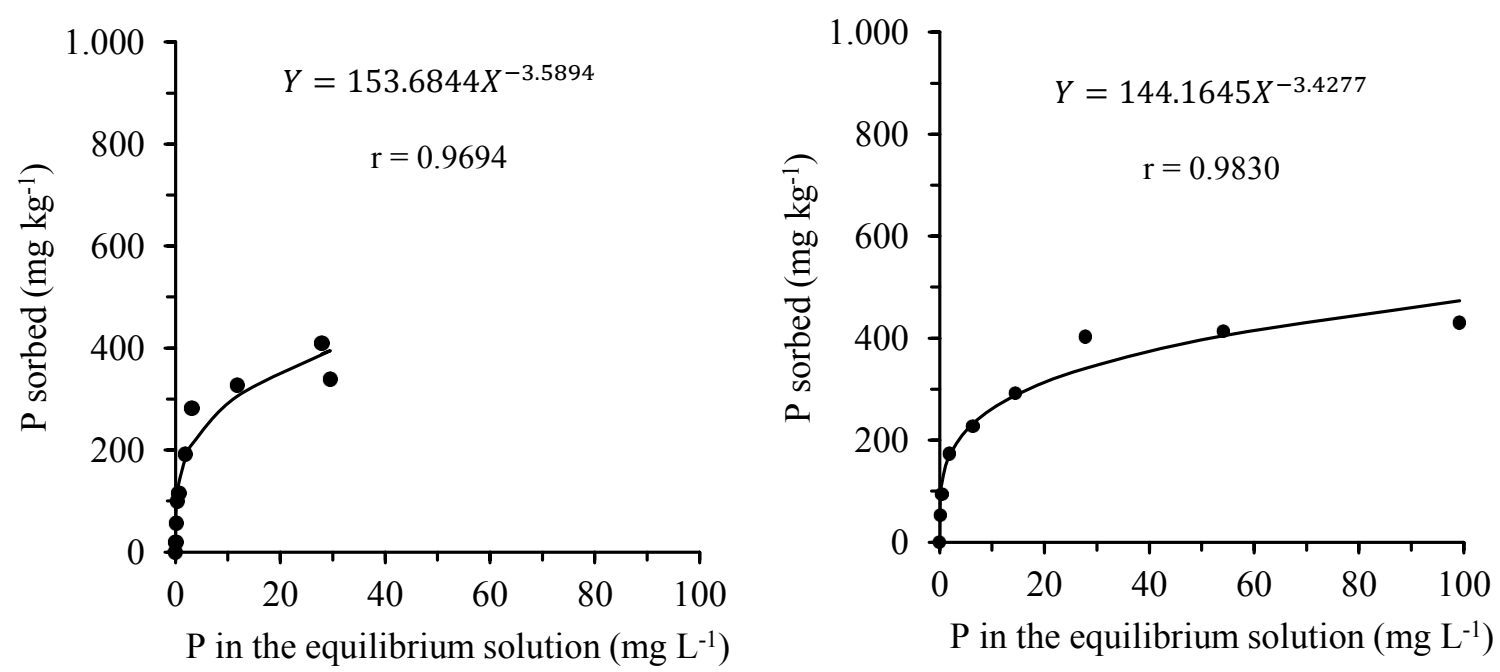

NQR = Typic Quartzipsamment (Neossolo Quartzarênico); LVM = Typic Hapludox (Latossolo Vermelho Amarelo); AVM = Typic Hapludult (Argissolo Vermelho Amarelo); NFC = Typic Quartzipsamment (Neossolo Flúvico); CHA = Typic Dystrudept (Cambissolo Haplico); CHB = Typic Dystrudept (Cambissolo Haplico)

Figure 3. Freundlich sorption isotherm for data of quantity of $\mathrm{P}$ sorbed in different soils. 
CRM

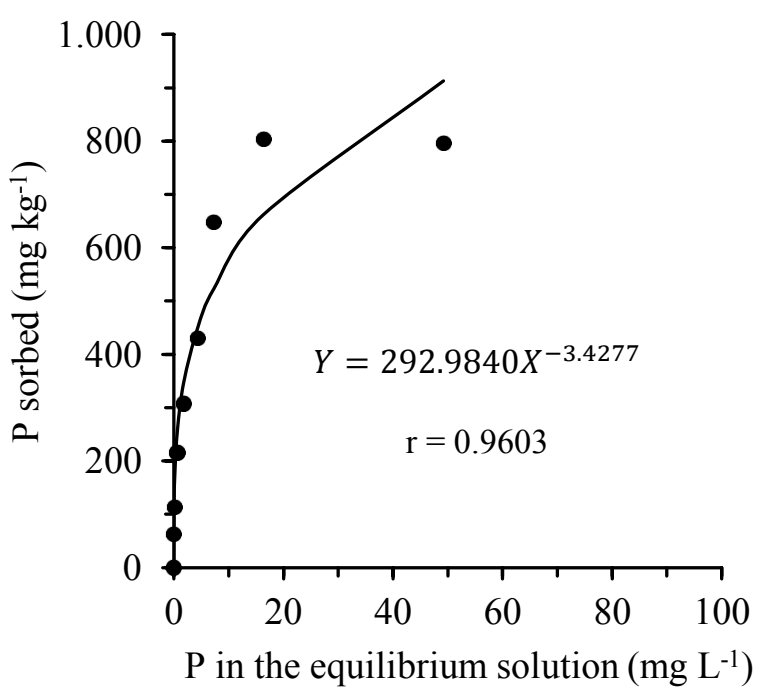

AVA

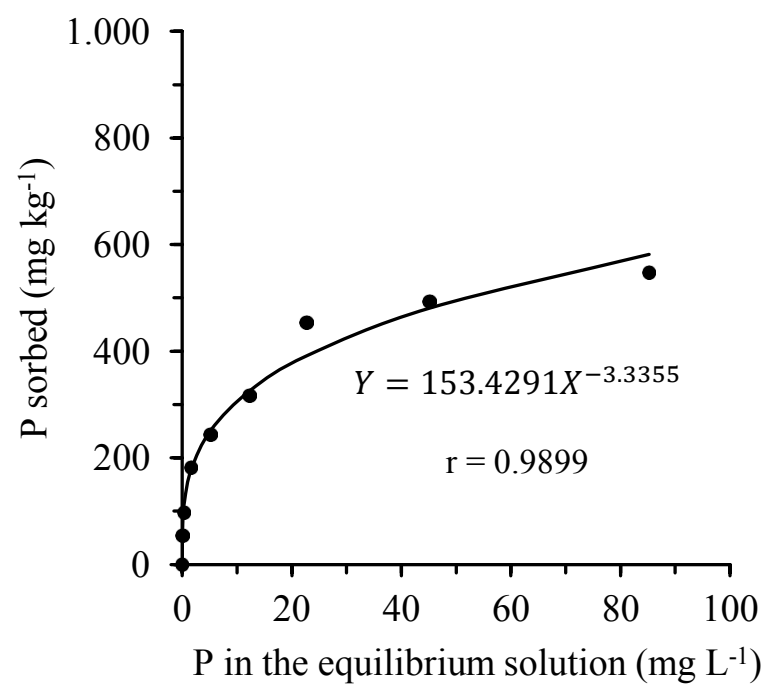

CHQ

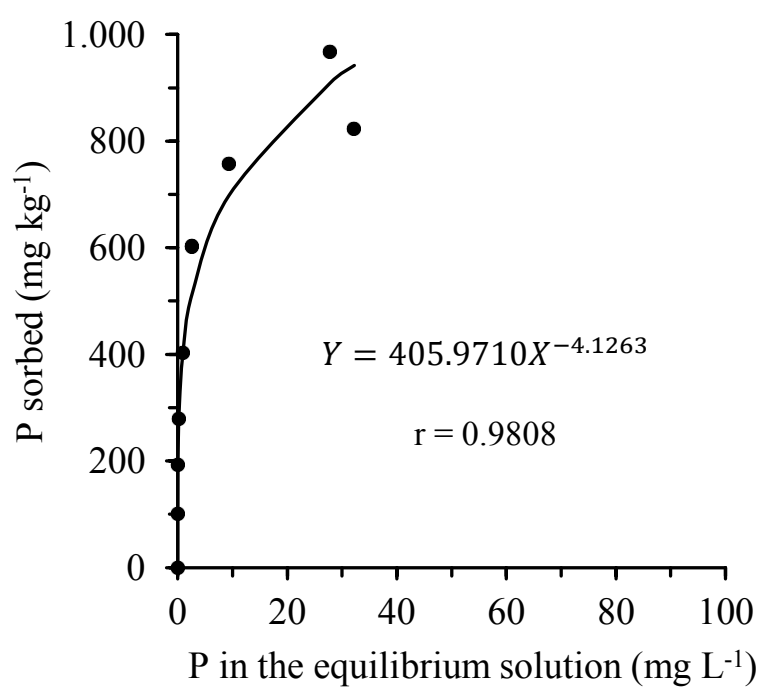

VHM

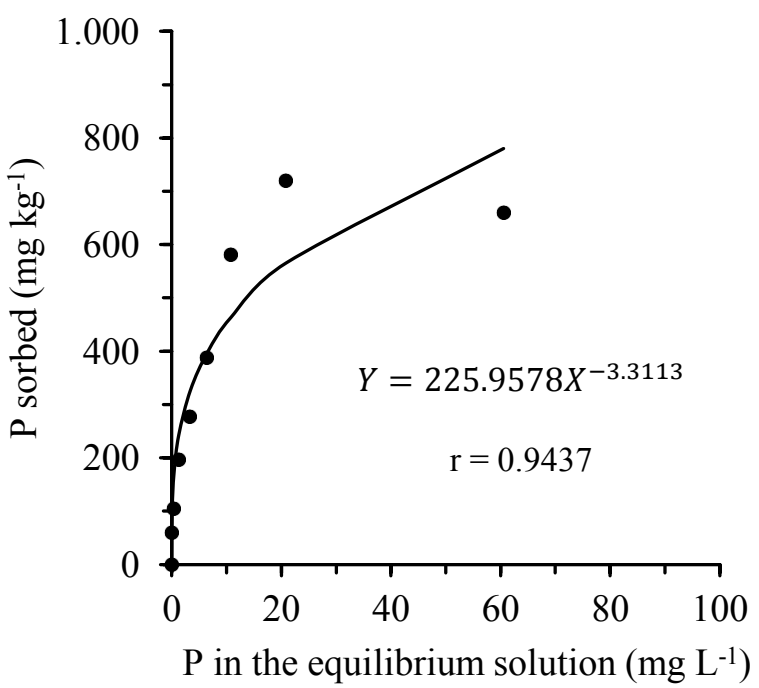

CRM = Typic Calciudolls (Chernossolo Rendzico); CHQ = Typic Dystrudept (Cambissolo Haplico); AVA = Typic Hapludult (Argissolo Vermelho Amarelo); VHM = Typic Hapludert (Vertissolo Haplico)

Figure 4. Freundlich sorption isotherm for data of quantity of $\mathrm{P}$ sorbed in different soils.

Table 3. Coefficients of simple linear correlation between parameters of the Langmuir and Freundlich sorption isotherms and soil characteristics that denote the phosphorus storage capacity of ten soils in the Semiarid region of Brazil.

\begin{tabular}{|c|c|c|c|c|c|}
\hline & $\mathrm{MPSC}^{(2)}$ & $\mathrm{a}$ & $\mathrm{k}$ & $\mathrm{n}$ & Clay \\
\hline P-rem & $-0.949^{* *}$ & $0.677^{*}$ & $-0.902^{* *}$ & $0.916^{* *}$ & $-0.841^{* *}$ \\
\hline Clay & $0.915^{* *}$ & $-0.632^{* *}$ & $0.820^{*}$ & $-0.765^{* *}$ & - \\
\hline $\mathrm{n}$ & $-0.807^{* *}$ & - & - & - & - \\
\hline $\mathrm{k}$ & $0.954^{* *}$ & - & - & - & - \\
\hline $\mathrm{a}$ & $-0.563^{*}$ & - & - & - & - \\
\hline
\end{tabular}

$*=$ significant at 5\%; ** = significant at $1 \%$; ns = not significant; constants of the Langmuir sorption isotherm: MPSC $=$ maximum $\mathrm{P}$ sorption capacity, and $a=$ binding energy of $\mathrm{P}$ to the soil; $k$ and $n=$ constants of the Freundlch model related to soil capacity to sorb the $\mathrm{P}$ from the equilibrium solution. 
The P-rem (Table 1) and MPSC (Table 2) found denote that the SPSC of these soils has high variation. CHQ, for example, present a MPSC 17.5fold that of NQR, which had the lowest SPSC. The highest MPSC values were found in CRM, CHQ, and VHM (Table 2), which presented high $\mathrm{pH}$, and $\mathrm{Fe}_{2} \mathrm{O}_{3}, \mathrm{Ca}^{2+}$, and clay contents (Table 1).

Mota, Assis Júnior and Amaro Filho (2004) evaluated the mineralogy of a Typic Dystrudept (Cambissolo Haplico) in Chapada of Apodi, RN, Brazil, and found higher iron and aluminum oxide contents than those found in a Typic Hapludox (Latossolo) and a Typic Hapludult (Argissolo) in this same region. Moreover, Moreira et al. (2006) evaluated the sorption of $\mathrm{P}$ in four soils of Ceará, Brazil, and found higher sorption of $\mathrm{P}$ in a Typic Dystrudept (Cambissolo Háplico); they attributed this result to the interaction between several factors, including the high total iron contents and free and amorphous iron oxides in this soil. These minerals are probably the main responsible for the high MPSC of soils (SANTOS et al., 2011).

The P-rem denotes not only the soil chemical and physical characteristics that affect the sorption of $\mathrm{P}$, but also mineralogical characteristics; the minerals of the clay fraction of CHQ probably had higher $\mathrm{P}$ sorption capacity than those of AVA. Moreira et al. (2006) and Broggi et al. (2011) found no trend of higher sorption of $\mathrm{P}$ in soils with higher clay contents, denoting the greater importance of the mineralogy of the clay fraction for the MPSC, when compared to clay contents.

The four sandy soils (NQR, LVM, AVM, and NFC) presented the lowest MPSC (Table 2), which is probably related to the low clay contents and high P-rem of these soils (Table 1). The sorption of $\mathrm{P}$ in sandy soils is lower because of the low quantity of mineral colloids that can adsorb $\mathrm{P}$ (SIMS; PIERZYNSKI, 2005).

The results found are consistent with those obtained by Arruda et al. (2017), who evaluated six soils and found higher P-rem in the most clayey soils. Similarly, Chaves et al. (2009) found higher MPSC in more clayey soils; and Jalali and Jalali (2016) found that limestone soils in Iran presented differences in $\mathrm{P}$ contents (extracted by different methods) and indicated a strong effect of soil texture on the sorption of $\mathrm{P}$, presenting a lower SPSC in more sandy soils and a higher SPSC in clayey soils.

A high clay content does not always mean high sorption of $\mathrm{P}$; however, the positive correlation found for clay contents and MPSC ( $\left.\mathrm{r}=0.915^{* *}\right)$ denotes the importance of this granulometric fraction for the explanation of $\mathrm{P}$ sorption processes in the soil. Moreover, the most clayey soils were, in general, those with higher sorption of $\mathrm{P}$ (Tables 1 and 2). This positive correlation between sorption of
$\mathrm{P}$ and clay contents is related to the large surface area of clays when compared to sand and to a larger number of positive charges that react and strongly connect to negatively charged phosphate ions in the soil solution (HADGU et al., 2014).

Farias et al. (2009) evaluated two soils groups in the state of Paraíba, Brazil, and found significant high correlation between MPSC and clay for a group of six less weathered soils, but found no significant correlation between MPSC and clay for a group of six more weathered soils. They attributed this result to the effect of the mineralogy of the clay fraction on the sorption of $\mathrm{P}$, mainly in more weathered soils.

Corrêa, Nascimento and Rocha (2011) evaluated soils in the state of Pernambuco, Brazil, and found positive and significant correlation between MPSC and clay contents; they reported that clay content and attributes can estimate the MPSC, and the clay type is important because of a large MPSC variation resulted from different clays in soils. The use of only one soil attribute, such as clay contents, as a criterion to recommend $\mathrm{P}$ fertilizers may result in errors, and the P-rem may be used, since it is a more reliable measure of SPSC (PINTO et al., 2013; ROGERI et al., 2016).

The correlations found between the constant $a$ related to the energy of sorption of $\mathrm{P}$ and P-rem $\left(\mathrm{r}=0.677^{*}\right)$ and clay contents $(\mathrm{r}=-0.632 * *)$ were statistically significant, but low $(\mathrm{r}<0.700)$. Thus, the binding energy of $\mathrm{P}$ to these soils is not surely lower in more clayey soils or in those that have lower Prem.

The sorption of $\mathrm{P}$ was higher in soils with more clayey textures, alkaline, and rich in $\mathrm{Ca}^{2+}$ and $\mathrm{Fe}_{2} \mathrm{O}_{3}$, such as the soils CHQ, AVA, and VHM. In these soils, the adsorption of $\mathrm{P}$ to the mineral colloid surfaces are probably as important as the precipitation of $\mathrm{P}$ bound to $\mathrm{Ca}^{2+}$, which has not the same energy of the $\mathrm{P}$ bound to iron and aluminum oxides, and can be used by plants, as reported by Santos et al. (2011).

Chaves et al. (2009) evaluated two soils of the Semiarid region of Brazil and found that the energy of adsorption of $\mathrm{P}$ was higher in the soil with lower clay contents. In addition, Matos et al. (2017) evaluated the sorption of $\mathrm{P}$ in soils of the Brazilian Amazon region and found that the binding energy of $\mathrm{P}$ to active sites decreases by being repelled by negative charges of clays. According to Novais and Smith (1999), it is not clear whether the P binding energy estimated by the Langmuir sorption isotherm can be a measure of the energy of $P$ retention in the soil. In this context, Farias et al. (2009) and Chaves et al. (2009) evaluated soils of the Semiarid region of Brazil and found no correlation between soil clay content and the binding energy estimated by the Langmuir sorption isotherm. 


\section{CONCLUSIONS}

The sorption of phosphorus $(\mathrm{P})$ was higher in soils with more clayey texture, alkaline, and rich in iron and calcium.

The clay contents and P-rem in the soils studied were correlated with the maximum $\mathrm{P}$ sorption capacity of soils, but P-rem was superior to clay contents regarding the estimation of maximum $\mathrm{P}$ sorption capacity of the soils.

\section{REFERENCES}

ALBUQUERQUE, A. W. et al. Growth and yield of sugarcane as a function of phosphorus doses and forms of application. Revista Brasileira de Engenharia Agrícola e Ambiental, 20: 29-35, 2016.

ALVAREZ V, V. H. et al. Determinação e uso do fósforo remanescente. Boletim Informativo, 25: 27 32,2000 .

ARRUDA, J. A. et al. Fósforo remanescente em solos do Seridó Paraibano. Revista Principia, 35: 42 $-49,2017$.

BEZERRA, A. L. L. et al. Influência da calagem da adsorção de fósforo em diferentes solos do Estado do Ceará. Agropecuária Científica no Semiárido, 9: 01-05, 2013.

BRAGA, J. M.; DEFELIPO, V. B. Determinação espectrofotométrica de fósforo em extratos de solo e material vegetal. Revista Ceres, 21: 73-85, 1974.

BRASIL. Levantamento exploratórioreconhecimento de solos do estado do Rio Grande do Norte. Rio de Janeiro, RJ: Divisão de Pesquisa Pedológica, 1971. 531 p. (Boletim Técnico, 21).

BRITO NETO, J. F. et al. Phosphorus adsorption and its relationship to the physical and chemical characteristics with different soil classes. African Journal of Agricultural Research, 13: 419-424, 2018.

BROGGI, F. et al. Fator capacidade de fósforo em solos de Pernambuco mineralogicamente diferentes e influência do $\mathrm{pH}$ na capacidade máxima de adsorção. Ciência e Agrotecnologia, 35: 77-83, 2011.

CHAVES, L. H. G. et al. Características de adsorção de fósforo em Argissolos, Plintossolos e Cambissolos do Estado da Paraíba. Engenharia Ambiental, 6: 130-139, 2009.

CORRÊA, R. M.; NASCIMENTO, C. W. A.;
ROCHA, A. T. Adsorção de fósforo em dez solos do Estado de Pernambuco e suas relações com parâmetros físicos e químicos. Acta Scientiarum. Agronomy, 33: 153-159, 2011.

COSTA, D. B. et al. Adubação fosfatada em cana planta e soca em Argissolos do Nordeste de diferentes texturas. Revista Caatinga, 27: 47-56, 2014.

FARIAS, D. R. et al. Fósforo em solos representativos do Estado da Paraíba. I - Isotermas de adsorção e medidas do fator capacidade de fósforo. Revista Brasileira de Ciência do Solo, 33: 623-632, 2009.

GODINHO, V. P. C. et al. Adsorção de fosfatos em três solos da região semiárida do Rio Grande do Norte. Pesquisa Agropecuária Brasileira, 32: 819823, 1997.

HADGU, F. et al. Study of phosphorus adsorption and its relationship with soil properties, analyzed with Langmuir and Freundlich models. Agriculture, Forestry and Fisheries, 3: 40-51, 2014.

JALALI, M.; JALALI, M. Relation between various soil phosphorus extraction methods and sorption parameters in calcareous soils with different texture. Science of the Total Environment, 566: 1080-1093, 2016.

MATOS, C. H. L. et al. Phosphorus adsorption in soils under forest and savanna from Northern Amazon, Brazil. Semina: Ciências Agrárias, 38: 2909-2920, 2017.

MOREIRA, F. L. M. et al. Adsorção de fósforo em solos do Estado do Ceará. Revista Ciência Agronômica, 37: 7-12, 2006.

MOTA, J. C. A.; ASSIS JÚNIOR, R. N. A.; AMARO FILHO, J. A. Física, química e mineralogia de solos cultivados com melão na chapada do Apodi$\mathrm{RN}$ : interpretação de dados para o manejo. In: MENDONÇA, E. S. et al. (Eds.). Solo e água: aspectos de uso e manejo com ênfase no semiárido nordestino. Fortaleza, CE: Departamento de Ciências do Solo, UFC, 2004. v. 1, cap. 11, p. 242 273.

NOVAIS, R. F.; SMYTH, T; J. Fósforo em solo e planta em condições tropicais. 1. ed. Viçosa, MG: Universidade Federal de Viçosa, 1999. 399 p.

PAIVA, M. R. F. C. Fracionamento e efeito do tempo de contato do fósforo inorgânico em solos do semiárido. 2019. 59 f. Tese (Doutorado em Manejo de Solo e água: Área de Concentração em Manejo de Solo e Água no Semiárido) - 
Universidade Federal Rural do Semi-Árido, Mossoró, 2019.

PINTO, F. A. et al. P-sorption and desorption in savanna Brazilian soils as a support of phosphorus fertilizer management. Ciência e Agrotecnologia, 37: 521-530, 2013.

ROGERI, D. A. et al. Substitution of clay content for P-remaining as an index of the phosphorus buffering capacity for soils of Rio Grande do Sul. Revista Brasileira de Ciência do Solo, 40: 1-13, 2016.

ROSSI, M. M. S; ROLLÁN, A. A.; BACHMEIER, O. A. Available phosphorus in the central area of the Argentinean Pampas. 2: Kinetics of adsorption and desorption of phosphorus under different soil and management environments. Spanish Journal of Soil Science, 6: 145-157, 2016.

SANTOS, H. C. et al. Kinetics of phosphorus sorption in soils the state of Paraiba. Revista Brasileira de Ciência do Solo, 35: 1301-1310, 2011.

SANTOS, H. C. et al. Phosphorus availability as a function of its time of contact with different soils, Revista Brasileira de Engenharia Agrícola e Ambiental, 20: 996-1001, 2016.

SANTOS, V. R. et al. Phosphate sources and their placement affecting soil phosphorus pools in sugarcane. Agronomy, 8: 283-298, 2018.

SIMS, J. T.; PIERZYNSKI, G. M. Chemistry of phosphorus in soils. In: TABATABAI, M. A.; SPARKS, D. L. (Eds.). Chemical processes in Soils. Madison: SSSA, 2005. cap. 2, p. 151-192.

TAMUNGANG, N. E. B. et al. Phosphorus adsorption isotherms in relation to soil characteristics of some selected volcanic affected soils of Foumbot in the West Region of Cameroon. International Journal of Soil Science, 11: 19-28, 2016.

TEIXEIRA, P. C. et al. Manual de métodos de análises de solo. Brasília, DF: EMBRAPA, 2017. $574 \mathrm{p}$.

TEIXEIRA, J. B. S.; SOUSA, R. O.; VALE, M. L. C. Phosphorus adsorption after drainage in two soil classes. Revista Ceres, 65: 196-203, 2018. 